\title{
Geomorphological Assessment to Tract the Flow Evolution of Kali Putih, Srumbung District, Magelang Regency, Central Java, Indonesia
}

\author{
Sari Bahagiarti Kusumayudha ${ }^{1 *}$, I Made Oki Sanjaya ${ }^{1}$, \\ Helmy Murwanto ${ }^{1}$, Sugeng Raharjo ${ }^{1}$ \\ ${ }^{1}$ Universitas Pembangunan Nasional Veteran Yogyakarta, Yogyakarta, Indonesia.
}

* Corresponding author : saribk@upnyk.ac.id

Tel.: +62 8122782595

Received: Nov 17, 2019. Accepted: March 13, 2020.

DOI: 10.25299/jgeet.2020.5.1.4096

\begin{abstract}
Kali Putih (The White River) is located in Srumbung district, Magelang regency, Central Java, Indonesia. It is originated from the upper slope of Merapi volcano,flowing to the Southwest direction. Kali Putih belongs to one of the most channels where frequently flowed by lahar of Merapi volcano. Based on geomorphological and geological traces found at the surrounding of modern Kali Putih channel, this indicated that the flow of Kali Putih has undergone displacement several times. The position of ancient river valley in the past has changed into the modern river valley in the present time. The existence of ancient Kali Putih is exhibitedby the presence of large dry valley morphology associated with volcanic blocks, gravels, and sand sized materials with various sorting, representing the characteristics of lahar and alluvial deposits. In the present time, the former river channelsare currently used by local people for agricultural and fisheries land.This researchwas conducted in order to analyse and determine the evolution of the ancient Kali Putih valleys, and the current river that acting as a collecting channel of lahars and pyroclastic avalanches of Merapi volcano. By concerning to geological law of "the present is the key to the past", results of this research can be used as a reference for studies related to volcanic disaster mitigation of the surrounding area.
\end{abstract}

Keywords: Kali Putih, flow evolution, geomorphology, lahar

\section{Introduction}

One of some volcanic products generatedby such an active volcano is lahar, that belongs to the strongest erosion forces, destructive, and capable of creating disaster. Besides its high capacity of erosion and sedimentation, lahar flows also generally create a strong impact to the environment (Lavigne, et.al, 2000). Material deposits that exceed the capacity of such a river to hold, will bring environmental problems to downstream. Problems caused by lahar sedimentation can be in the form of the closure of irrigation channels, siltation of the riverbed, and the buried of land around the river channel due to overflow of lahar which is not able to be accommodated by the river. Changes in flow of the river's morphology caused by lahar include widening of the river channel, streamlining of the river flow, and silting of the riverbed (Murwanto, et.al, 2013).

In the research area, there is a river, namely Kali Putih (the White River) which often used by lahar as the secondary product of Merapi volcano eruption to flow (Murwanto, et.al, 2013). The river is located in Srumbung District, Magelang Regency, Central Java Province, Indonesia (Fig. 1), that belongs to an area with dense population. The local community mostly live in the adjacent of river flow, while the river itself is used to be threated by lahar.

Based on remote sensinganalysis using Earth's map and Google Earth imagery, there are found straightness of river paths which interpreted as the former of Kali Putih flows. This indicates that Kali Putih has ever changed its flow due to natural processes. In order to derive geohistorical data and information on Kali Putih and lahar disaster in the past time, then the evolution of Kali Putih flow is needed to be traced with scientific assessment in the form of geomorphological and geological studies.
This study aims to determine the evolution of the ancient Kali Putih valleys, and the current river that acting as a collecting channel of loose material, lahars or volcanic mud flows, and pyroclastic avalanches of the Merapi volcano.
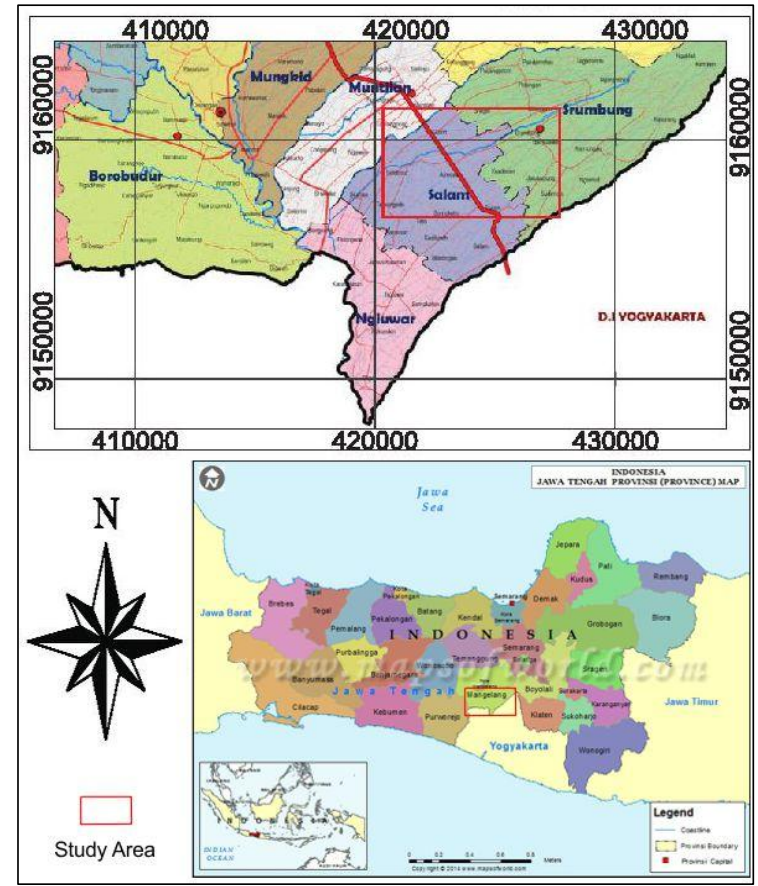

Fig. 1. Location map of the Research area

\section{Methods of the Study}

Method carried out in this study is descriptive, and analytic, combining with assessment on Merapi volcanic 
history and field observation by conducting geological and geomorphological mapping. Data to be assessed including secondary and primary data. The secondary data were satellite imageries, Peta Rupa Bumi Indonesia (Indonesian map of earth appearence) and regional geological map of Merapi volcano, while primary data in terms of geomorphological and lithological characteristics were derived from field survey and mapping.

Field survey and mapping activities done in this research can be divided into several stages, including data acquisition, literature review, analyses on flow patterns, geomorphology, stratigraphy, geological structure, and petrology, and synthesis related to identification of the evolution of Kali Putih flows.

\section{Results and Discussion}

\subsection{Geomorphology}

In the present time Kali Puth flow is situated on the southwestern slope of Merapi volcano. Places flown by Kali Putih are Cabe Kidul, Ngaglik, Remame, Jumoyo Kidul, Pendem, Seloboro, Tersangede, Baturono. There are some ancient valleys that interpreted as the former Kali Putih flows.The first valleyis found in Srumbung Kidul, Kemiren, Jumoyo Lor, Pulosari, Pendem, Seloboro, and Gajahan. The secondvalleyis discovered in Srumbung, Gempol, and Seloboro. The valley of modern Kali Putih itself issituated in Srumbung area, Jumoyo, and Seloboro.

In order to study the evolution of Kali Putih flow, the geomorphology of the surrounding area needs to be analysed. However, landform has an important role to control erosion and flow of surface water. Referring to Setyawati \& Ashari (2017), the Srumbung district is situated on the southwestern slope of Merapi volcano, the landforms can be divided into volcanic food slope, volcanic footplain, and isolated hills (Fig. 2).

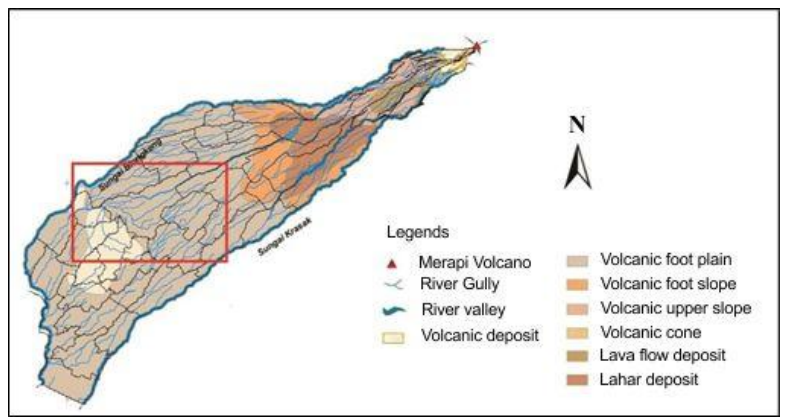

Fig. 2.Geomorphologic map of the southwestern slope of Merapi volcano (Setyawati \& Ashari, 2017). Red box shows situation of the research area.

Field observation on the ancient Kali Putih channels was carried out to determine the position of the previous Kali Putih flow. This observation is related to geomorphology that consisting of assessment on morphology, morphometry (valley shape, valley width and valley length), passive morphostructure (lithology), and morpho-association. Based on this study, the geomorphology of the research area can be devided into for geomorphic units, namely volcano footslope unit, rever channel unit, isolated hill unit, and isolated ranges unit. Geomorphological map of the research area is displayed in Fig.3.

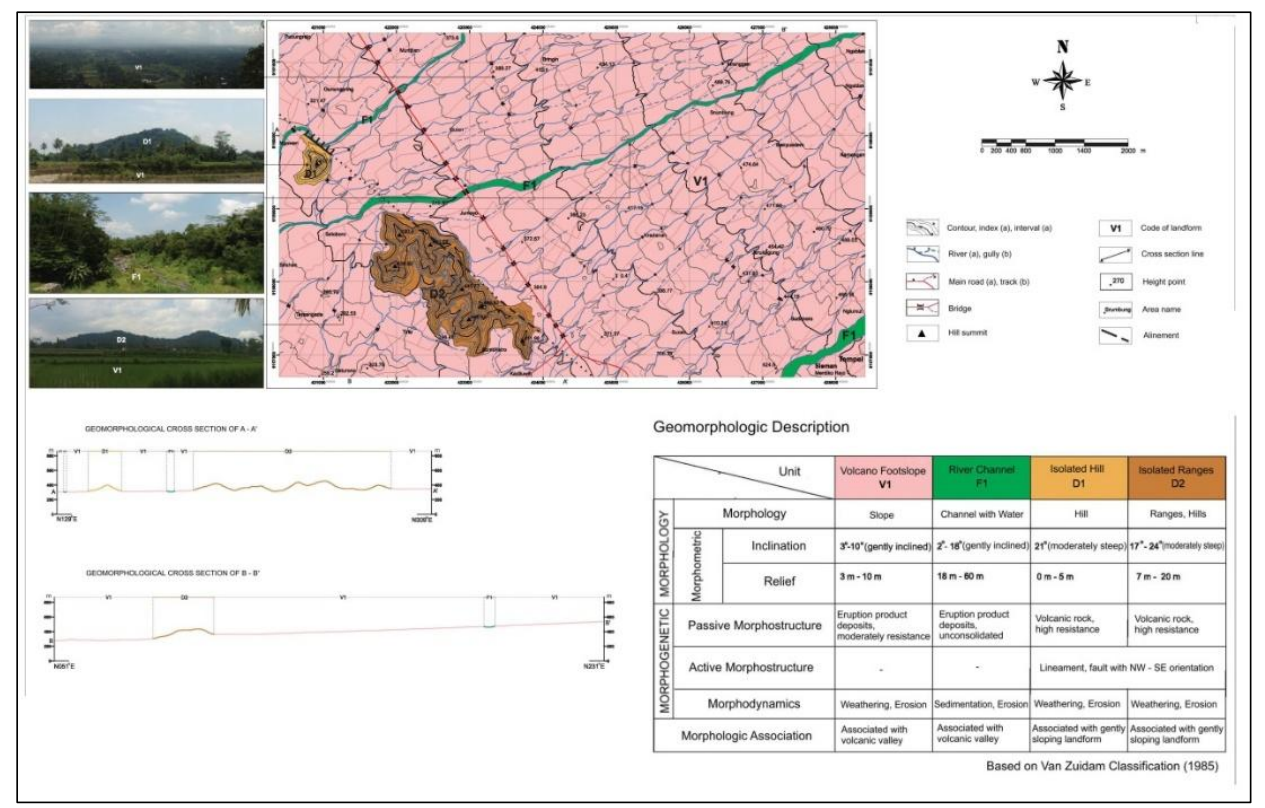

Fig 3. Geomorphological Map of the Research area

\subsection{Geology}

Mainly, geology of the research area is influenced by Merapi volcano activities. Product of the volcanicactionscan be in the forms of primary yield as pysoclastics, and secondary creation as lahar. There are two kinds of Merapi volcano pyroclastics,called fall pyroclastics, and flow or avalanche pyroclastics (Kusumayudha, 2017). Lahar is a debris and mud concentration formed from a mixture of water, particles, sand, and boulders (Paripurno, 2009). The source of water can be rainfall, crater lakes,or melting of ice, while the particles come from pre-existing pyroclastic avalanches as well as material produced directly from eruptions.

Primary Lahar occurs in volcanoes that there is a crater lakes. The base of its crateris impermeable so that a number of rainwater will be collected inside. If the volume of water in the crater is large enough, when an eruption occurs it can spill hot mud with temperatures reaching above $100^{\circ} \mathrm{C}$ (Lavigne, et.al, 2000).

Rainy lahar (secondary lahar) or better known as cold lahar occurs when volcanic materials that have not been consolidated on peaks and slopes, at or after the eruption, then 
mixed with rainwater.These pyroclastic materials will be transported and move downward as a high density of flow.(Lavigne, et.al, 2000).

Lahar belongs to one of the strongest erosion forces. Sedimentation by lahar flows that exceed the river's boundary limits generally brings environmental problems downstream,such as siltation of the riverbed, closure of irrigation channels, and buried of land around the river channel. It is due to the overflow of material lahar that can not be accommodated by the riverpassage. Environmental changes due to lahar overflows include transformations in river flow morphology, such as channels widening, basins streamlining and siltation, and sedimentation characteristicschanging (Thouret, et.al, 2000).

Lahar flow velocity is influenced by slope inclination, rainfall intensity, and material volume. The steeper the slope, the speed of the lahar flow will increase (Thouret, et.al,
2000).Genetically lahar is divided into two types, namely lahar of eruption (primary) and lahar of rainfall (secondary).

Based on characteristics of the dominant lithology, and refering to the regional stratigraphy according to Wirakusumah, et al. (1989) and Paripurno (2009), the rock units in the research area are determined as composed of Gendol lava units, Merapi lahar deposit lunits, Merapi lahar deposit 2 units and alluvial deposits.

Referring to Wirakusumah, et al. (1989) and Camus et.al. (2000), the Gendol lava unit belongs to the oldest old rock groupin Srumbung area, it is Tertiary geological age. The stratigraphic relationship between Gendol lava units and Merapi lahar deposit 1 unit is nonconformity.The stratigraphic relationship between the Merapi lahar deposit lunit and the Merapi lahar deposit 2unit is aligned.The geologic map of the research area is shown in Fig. 4.

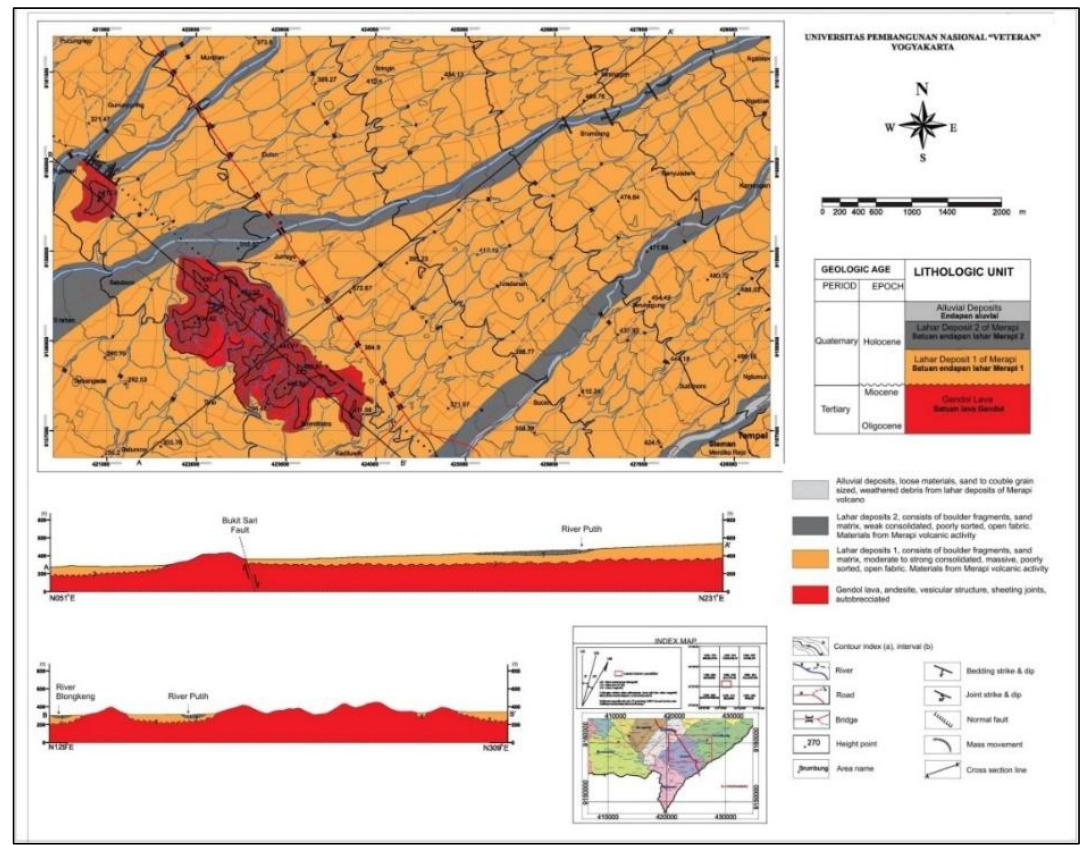

Fig 4. Gerological map of Kali Putih and surrounding area

\subsection{Merapi Activity History}

Before the year 1994, say 1960(s), 1930(s), 1900(s) etc eruptions of Merapi volcano generally toward southwestern direction (Kusumadinata, 1979). Characteristics of the eruptions were variation of volcanian, pelean, and merapian types (Kusumayudha, et.al, 2019). All of the types of eruption generally produced pyroclastics that deposited on the western flank of the volcano. When the deposits mixed with rain water to became more dense and heavy, then flowed downward lead by gravity, forming lahar (Kusumayudha, 2017). Because of this situation, the research area always passed by pyroclastic and lahar flows of that times. Due to its role as the area of where always flown by lahar and pyroclastic, subsequentlythis area lithologically composed of pyroclastic and lahar deposits.

Kali Putih is one of the rivers that flows to the southwest of Mount Merapi.The river is frequentlyaffected by rain lahar flows. Based on the historical records, this river had been fed by lahar on November 21-25 1975, March 6, 1976, November 20-27, January 1993, July 1998 (Lavigne, et.al, 2000), and in the end of 2010to 2011 (Kusumayudha, et.al, 2019).

The potential of lahar flow in the Kali Putih is still quite large. It is supported by the fact that there are still many materials in the upper slope, as well as the high potential for rainfall. This huge potential is a serious threat to changes the morphology of Kali Putih channel. By refering to "the present is the key to the past", it can be strongly pressumed that Kali Putih has undergone such a flow evolution.

There has been some ancient Kali Putih grooves, indicated bythe presence of a wide valley morphology with lahar deposits in the form of andesite blocks. The existence of a large valley and the presence of lahar deposits prove that the area was once a river channel that had been flowedby lahar. Ancient Kali Putih grooves can be found in the Srumbung area to Salam. Some of the former areas of the Kali Putih channel are used by the community as agricultural and fisheries land.

As has been mentioned above, the existence of ancient Kali Putih in the research area can be observed based on geological and geomrophological aspects, including morphometric, morphogenesis, and morpho-association. Results of the assessment pointed that kali Putih was subjected toflow displacement three times.

\subsubsection{Kali Putih Evolution}

\section{a. Ancient Kali Putih 1}

The ancient Kali Putih 1 is found in the areas of Cabe Kidul, Ngaglik, Babadan, Remame, South Jumoyo, Pendem, Seloboro, Tersangede and Baturono. The upper reaches of the river is in the Northeast of Lombok Kidul (Fig.5.). The geomorphological aspects are as follows: 
Table 1. geomorphological aspects Kali Putih 1

\begin{tabular}{ll}
\hline Morphography & $\begin{array}{l}\text { Longitudinal valley, river terraces with flow direction from northeast to } \\
\text { southwest, dammed by Gendol Hills, afterwardturn around the hills, and then } \\
\text { turn back to flow to relatively southwestward direction (Fig. 5, Fig.6.). }\end{array}$ \\
\hline Morphometry & a. valley shape:“U” \\
& b. valley width: 30-60 meter \\
Active Morphostructure & Lahar deposits and alluvial deposits (Fig.7.). \\
Morphographic Association & Volcanic food slope, volcanic food plain, isolated hills \\
\hline
\end{tabular}

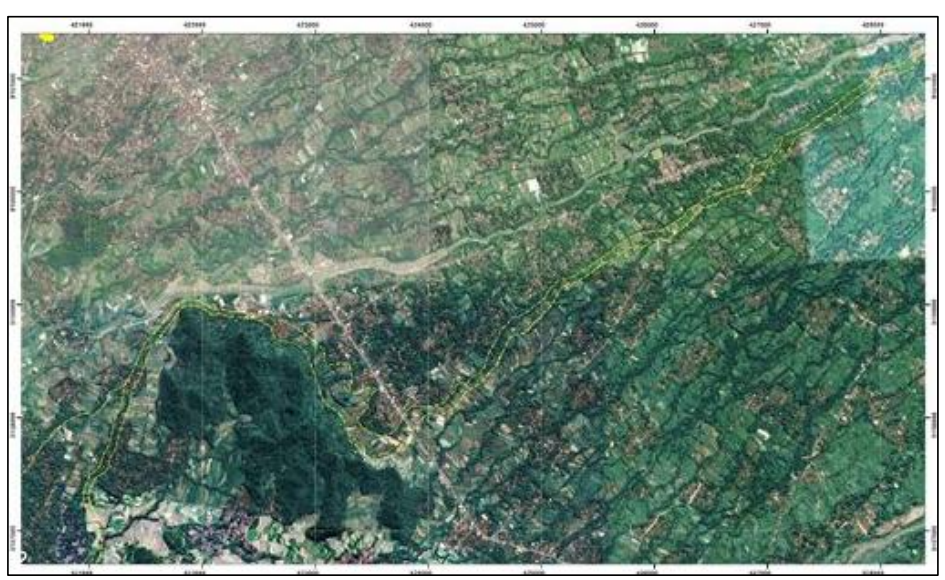

Fig 5. Ancient Kali Putih 1. Dash lines show the old channel of ancient Kali Putih 1 (Photo Source: Google Earth).

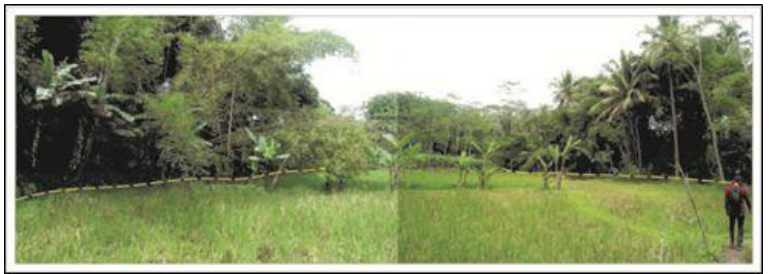

Fig 6. Old channel of ancient Kali Putih 1.

\section{b. Ancient Kali Putih 2}

Ancient Kali Putih 2 is found at villages of Srumbung Kidul, Jamblang, Kemiren, Jumoyo Lor, Pulosari, Pendem, Seloboro

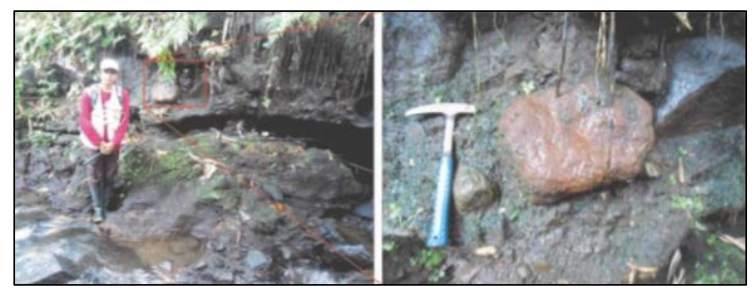

Fig 7.Old lahar depositson the ancient Kali Putih 1 river bank. following:

Table 2. geomorphological aspects kali putih 2

\begin{tabular}{|c|c|}
\hline Morphography & $\begin{array}{l}\text { Longitudinal valley, river terraces with flow direction from northeast to southwest, } \\
\text { dammed by Gendol Hills, afterwardturn around the hills, and then turn back to flow } \\
\text { to relatively southwestward direction (Fig. 8, Fig.9.). }\end{array}$ \\
\hline Morphometry & $\begin{array}{ll}\text { a. } & \text { valley shape: "U" } \\
\text { b. } & \text { valley width: } 30-92 \text { meter }\end{array}$ \\
\hline $\begin{array}{l}\text { Active } \\
\text { Morphostructure }\end{array}$ & Lahar deposits and alluvial deposits (Fig.10.). \\
\hline $\begin{array}{l}\text { Morphographic } \\
\text { Association }\end{array}$ & Volcanic food slope, volcanic food plain, isolated hills \\
\hline
\end{tabular}

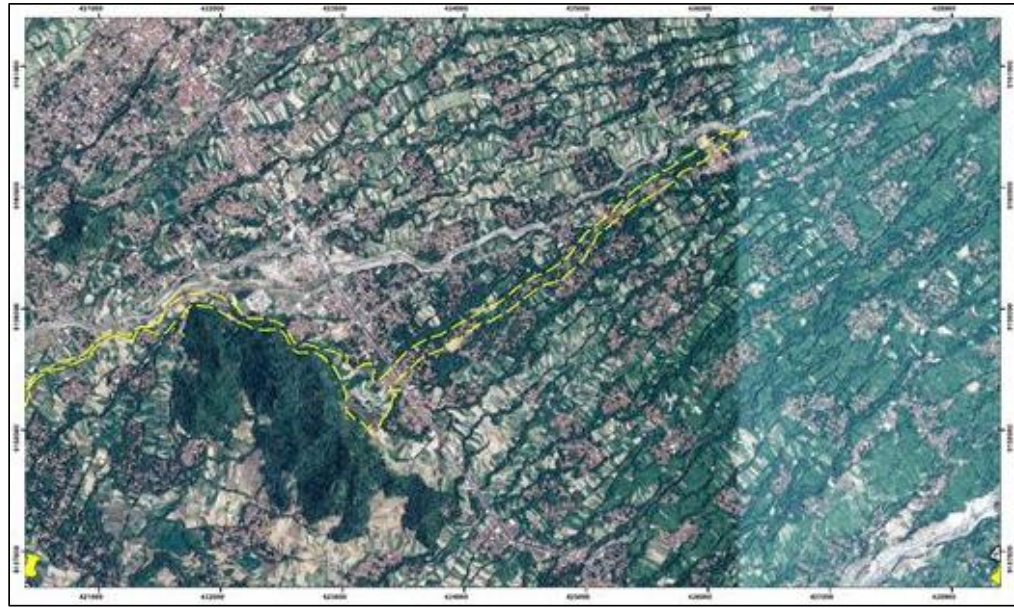

Fig 8. Ancient Kali Putih 2. Dash lines show the old channel of ancient Kali Putih 2 (Photo Source: Google Earth). 


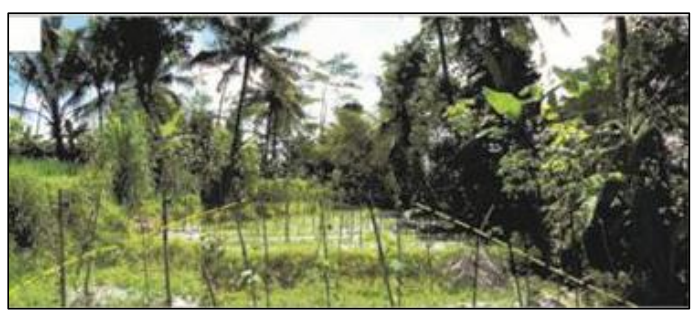

Fig 9. Old channel of ancient Kali Putih 2 at Gajahan village

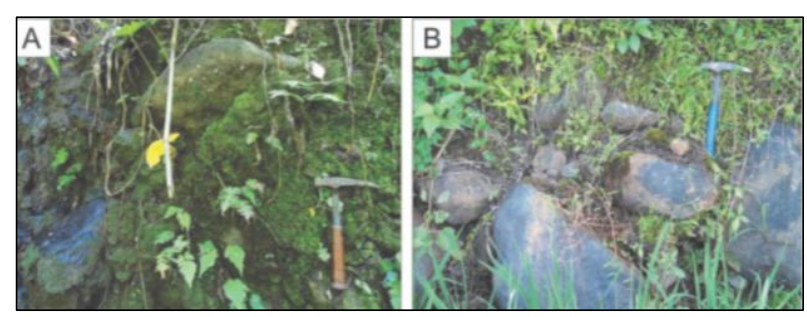

Fig 10. Old lahar depositson the river bank of ancient Kali Putih 2 atPendem village (A); at Gajahan village (B).

\section{c. Ancient Kali Putih 3}

Ancient Kali Putih 3 is discovered in Gempol village (Fig.

11.). The geomorphological aspects are as the following:

Table 3. geomorphological aspects kali putih 3

\begin{tabular}{ll}
\hline Morphography & $\begin{array}{l}\text { Longitudinal valley and river banks with flow direction relatively northeast - } \\
\text { southwest without colliding Gendol Hills (Fig. 11, Fig. 12.). }\end{array}$ \\
\hline Morphometry & a. valley shape: "U" \\
& b. valley width: 26-78 meter \\
Active Morphostructure & Lahar deposits and alluvial deposits (Fig. 13.). \\
Morphographic Association & Volcanic food slope, volcanic food plain \\
\hline
\end{tabular}

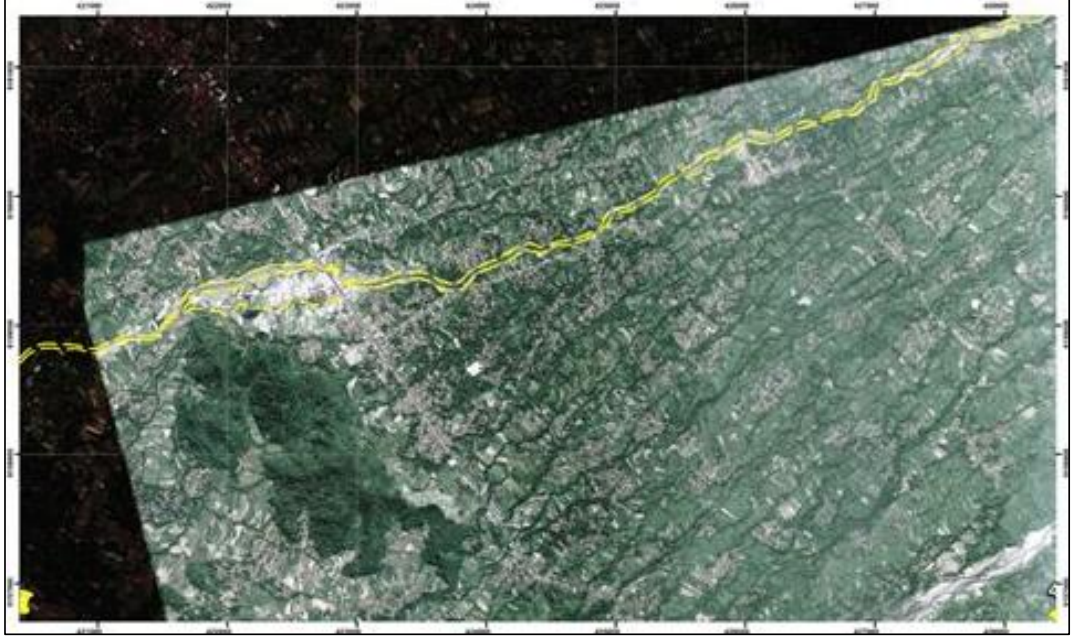

Fig. 11. Ancient Kali Putih 3.Dash lines show the old channel of ancient Kali Putih 3 (Photo Source: Google Earth).

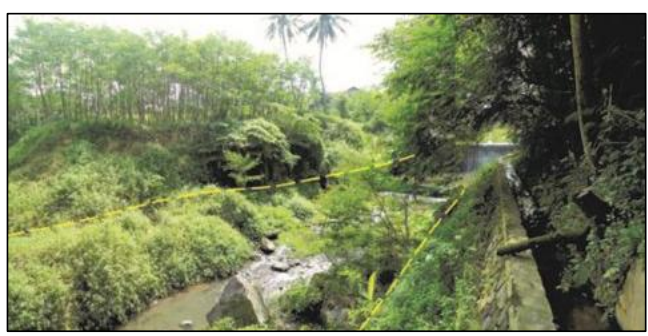

Fig. 12. Ancient Kali Putih 3 at Gempol village.

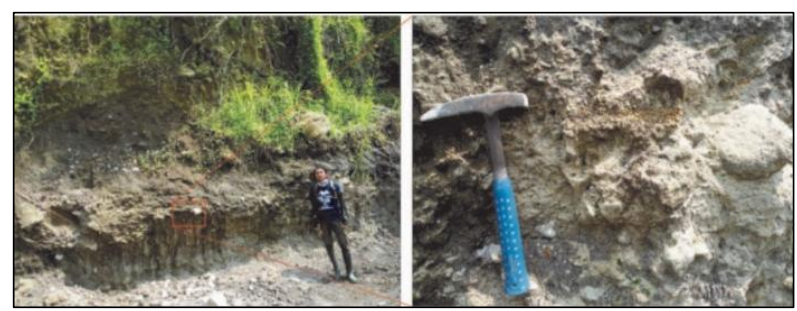

Fig. 13.Old lahar deposits on the ancient Kali Putih 3 river bank at Gempol village.

\section{d. Modern Kali Putih}

Modern Kali Putih can be found at Salam, Jumoyo, and Srumbung areas (Fig. 14.). The geomorphological aspects are as the following:

\begin{tabular}{ll}
\multicolumn{2}{c}{ Table 4. geomorphological aspects Modern Kali Putih } \\
\hline Morphography & Longitudinal valley of northeast - southwest direction (Fig. 14, Fig. 15.). \\
\hline Morphometry & a. valley shape: "U"' \\
& b. valley width: 30-60 meter \\
Active Morphostructure & Lahar deposit and alluvial deposit (Fig.16.). \\
$\begin{array}{l}\text { Morphographic } \\
\text { Association }\end{array}$ & Volcanic food slope, volcanic food plain \\
\hline
\end{tabular}




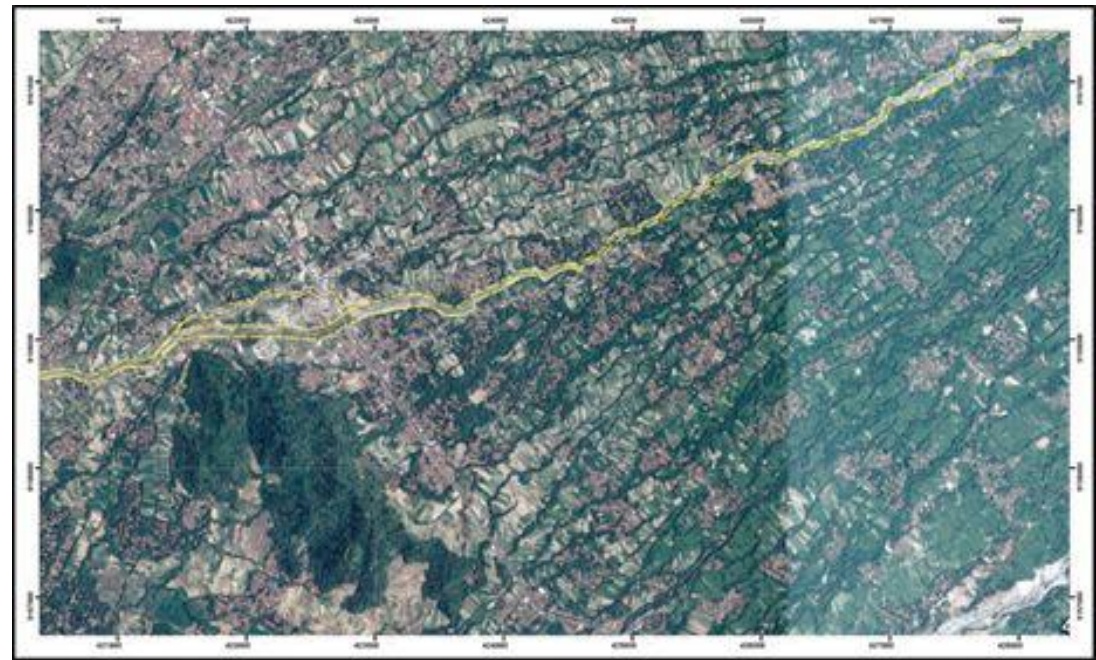

Fig14. Modern Kali Putih.Dash line shows the old channel of modern Kali Putih (Source: Google Earth).

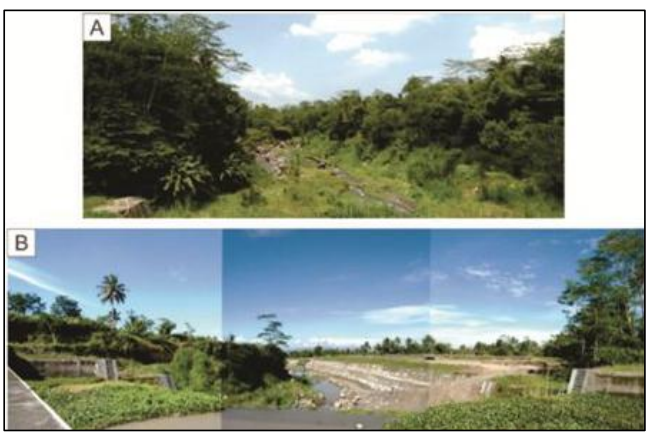

Fig 15. Modern Kali Putih channel at Pondok area (A);at Karanggowang area (B).

Based on the above analysis, it can be concluded that Kal Putih has undergone three times flow displacement, which started from the ancient Kali Putih 1, the ancient Kali Putih 2, the ancient Kali Putih 3, and become themodern Kali Putih. The displacement was due to the damming of the river channel

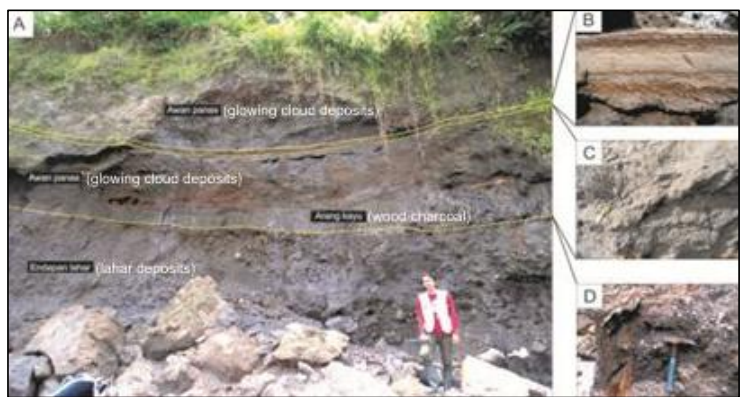

Fig 16. Lahar and pyroclstics (flow pyroclastic, glowing cloud) deposits on the river bank of modern Kali Putih at Pondok area.

by volcanic materials so that the river water requireda way out and formed a new river channel.

The results of this study are a map of the evolution of Kali Putih in Srumbung Subdistrict, Magelang Regency, Central Java Province which can be seen in Fig.17.

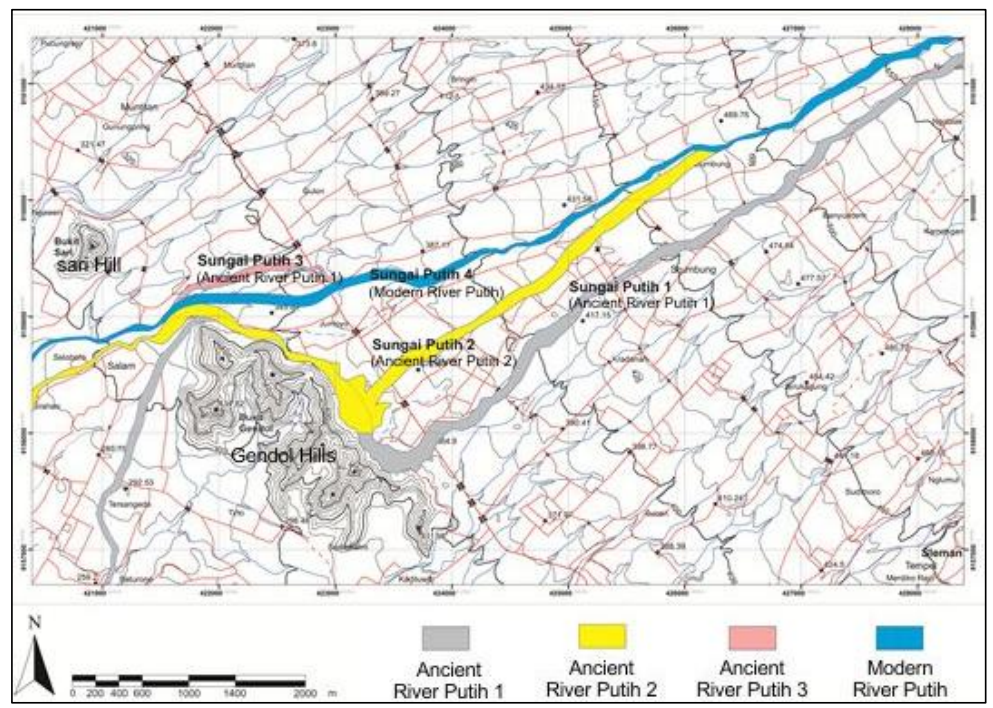

Fig. 17. Evolution map of the Kali Putih in Srumbung Subdistrict, Magelang District, Central Java.

The evidence of changes in river flow, the discovery of volcanic material, and the existence ofriver terracesreinforce the hypothesis on kali Putih channel evolution. Some informations from localcommunities,also further strengthens this hypothesis. The ancient Kali Putih 1 was estimated to be before $732 \mathrm{AD}$, as evidenced by the presence of the Canggal Inscription on Wukir Hill of $732 \mathrm{AD}$ (Murwanto, et al, 2013).
Ancient Kali Putih 2 is a subversionof the ancient Kali Putih 1 flow caused by the damming of the river by volcanic material so that the river water looks for a way out by creating the flow of the ancient Kali Putih 2. According to Murwanto, et al. (2013), the ancient Kali Putih 3 in the Gempol area was the previous Kali Putih which was moved by the Dutch Colonial 
Government to facilitate the construction of MagelangYogyakarta connecting road.

Nowadays the ancient Kali Putih channels are used by the local people for farming and fisheries, while the modern Kal Putih flow is still potential of hit by lahars inthe future. Due to the dense population of the surrounding area, in order for disaster mitigation, it is necessary to make serious efforts so that the river banks are not used as settlements.Some embankments are need to be built along the riverbanks, and also need to pay attention to bridge constructions that pass through the river often flownby lahar.

\section{Conclusions}

Based on the results of geological and geomorphologicalanalyses by using RBI map and Google Earth's imagesin this study, some conclusions can be summerized, as the following:

1. The geology and geomorphology of Srumbung Area are strongly influenced by Merapi volcano activities and eruption producs, such as pyroclatics and especially lahars.

2. There is a river, called kali Putih that its origin is from the upper part of Merapi volcano. Based on the historical records,Kali Putih that flows to the southwest, frequentlybe affected by lahar flows.

3. Kali Putih flow in Srumbung areahas undergone three times flow displacement, which started from the ancient Kali Putih 1, the ancient Kali Putih 2, the ancient Kali Putih 3, and become themodern Kali Putih.

4. The displacement of Kali Putih cnannel was due to the damming of the river channel by volcanic materials so that the river water required a way out and formed a new river channel.

5. For disaster mitigation, the river banks are suggested not to be used as settlements.Embankments need to be built along the riverbanks, and bridges that pass through the river often flown by lahar need such a special construction.

\section{References}

Anonim, 2006-2013, Google Earth

Camus, G., Gourgaud, A., Mossand-Berthommier, p.C., Vincent, P.M., 2000, Merapi (Central Java, Indonesia): An outline of the structural and magmatological evolution, with a special emphasis to the major pyroclastic events, Journal of Volcanological and
Geothermal Research, Vol 100, Elsevier: 139-163, URL: http://www.elsevier.nl/locate/jvolgeores

Kusumadinata, 1979,Data Dasar Gunungapi Indonesia (Basic data of Volcanoes of Indonesia), Departemen Pertambangan dan Energi R. I.

Kusumayudha, S.B. 2017, Gunungapi Aktif Indonesia (Active Volcanoes of Indonesia), Adicita Parama Yogyakarta.

Kusumayudha, S.B, Murwanto, H, Sutarto, Choiriyah, U, 2019, Volcanic Disaster and the Decline of Mataram Kingdom in the Central Java, Indonesia, 2nd Geomeast International Congress \& Exhibition Proc., p $83-93$, URL: http://link.springer.com/chapter/10.1007/978-3030-02032-3 8\#citeas

Lavigne, F., J.C. Thouret, B. Voight, H. Suwa, A. Sumaryono. 2000. Lahars at Merapi Volcano, Central Java: an Overview. Journal of Volcanology and Geothermal Research,423-456,

URL: http://www.elsevier.n1/locate/jvolgeores

Murwanto H., Siregar D.A., Purwoarminta, A. 2013. Jejak Erupsi Gunung Merapi di Kabupaten Magelang Provinsi Jawa Tengah (The Tracts of Merapi Volcano Eruptions in Magelang Regency, Central Java). Jurnal Lingkungan dan Bencana Geologi. 135-147.

Paripurno, E.T. 2009, Karakter Lahar Gunung Merapi Sebagai Respon Perbedaan Jenis Erupsi Sejak Holosen (The Characteristics of Merapi Volcano Lahar as the Response of Eruption Type Difference Since Holocene), Universitas Padjadjaran, Bandung

Setyawati, S. \& Ashari, A. 2017. Geomorfologi Lereng Baratdaya Gunung Api Merapi Kaitannya Dengan Upaya Pengelolaan Lingkungan Dan Kebencanaan (Geomorphology of the Southwest Slope of Merapi Volcano Related to Environmental and Disaster Management). Geomedia, Vol 15, No. 1, DOI: https://doi.org/10.21831/gm.v15i1.16235

Thouret, J.C., Lavigne, F., Kelfoun, K., Bronto, S. 2000, Toward a revised hazard assessment at Merapi volcano, Central Java, Journal of Volcanology and Geothermal Research, Vol 100, Elsevier: 479-502.

Wirakusumah, A. D., Juwarna H., Loebis H.. 1989. Peta Geologi Gunungapi Merapi, Provinsi Daerah Istimewa Yogyakarta \& Jawa Tengah (Geological Map of Merapi Volcano, Yogyakarta Special Territory and Central Java Provinces). Bandung: Badan Geologi.

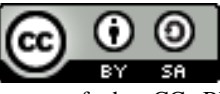

(C) 2020 Journal of Geoscience, Engineering, Environment and Technology. All rights reserved. This is an open access article distributed under the terms of the CC BY-SA License (http://creativecommons.org/licenses/by$\mathrm{sa} / 4.0 /)$. 